\title{
IDENTIFICATION OF MAIZE LANDRACES WITH HIGH LEVEL OF RESISTANCE TO STORAGE PESTS Sitophilus zeamais Motschulsky AND Prostephanus truncatus Horn IN LATIN AMERICA
}

\author{
IDENTIFICACIÓN DE VARIEDADES NATIVAS DE MAÍZ CON ALTA RESISTENCIA A \\ LAS PLAGAS DE ALMACÉN Sitophilus zeamais Motschulsky Y \\ Prostephanus truncatus Horn, EN LATINOAMÉRICA
}

\author{
Silverio García-Lara ${ }^{1 \star}$ and David J. Bergvinson ${ }^{2}$
}

\author{
${ }^{1}$ Department of Biotechnology and Food Engineering, ITESM-Campus Monterrey, Tecnológico de Monterrey. 64849, Monterrey, N.L. Tel.: +52 81 8358 1400 ; Fax: \\ +52 818328 4262. ${ }^{2}$ Agricultural Development. Gates Foundation. PO Box 23350. 98102, Seattle, WA. USA. \\ *Autor para correspondencia (sgarcialara@itesm.mx)
}

\section{SUMMARY}

The maize weevil (MW) (Sitophilus zeamais), and the larger grain borer (LGB) (Prostephanus truncatus) are major storage pests causing serious losses in maize (Zea mays L.) in developing countries of Latin America (LA). This study identified maize landraces with high levels of resistance to MW and LGB by screening 1171 genotypes collected from 24 LA countries in 38 sampling areas. Maize grain weight losses (GWL), total dust production (TDP) and number of adult progeny (NAP) were measured for LGB and MW attack in each genotype. Susceptibility traits to MW and LGB were related to specific geographical location. Range of resistance for MW was from 0.6 to $51 \%$, while for LGB from 0.1 to $66 \%$. Approximately $28 \%$ of the analyzed genotypes showed high level of resistance to MW, with Antilles region offering the most resistant accessions with races of EarCar, Chande, Haitye, Nal-Tel, Tuson, and Canill. Resistance to LGB was observed in $22 \%$ of genotypes analyzed with accessions from Southern México with races of Cónico, Nal-Tel, Vandeño, Elotes Occidentales, Cubano, Tuxpeño, and Tepecintle. Low correlation $(r=0.28 ; P<0.01)$ between maize resistance to $M W$ and LGB indicated a divergent adaptive response of maize grain to these two pest. Geographic data showed a negative correlation between latitude and longitude with $\mathrm{MW}$ resistance traits being significant only for longitude $(r=-0.253 ; P<0.05)$. Opposite trend of correlations, positive but not significant, was observed for LGB resistance traits. These results indicate an influence of geographic location in local varieties being selected for storage pest resistance over time. Genotypes with excellent postharvest insect resistance have now been identified for maize breeders to use in developing improved cultivars for use in LA.

Index words: Zea mays, landraces, maize weevil, larger grain borer, insect-resistance.

\section{RESUMEN}

El gorgojo del maíz (GM) (Sitophilus zeamais) y el barrenador grande del grano (BGG) (Prostephanus truncatus), son las principales plagas de los productos almacenados y causantes de graves pérdidas de maíz (Zea mays L.) en los países en desarrollo de América Latina (AL). Este estudio se realizó para identificar las razas nativas de maíz con alta resistencia al GM y BGG, en 1171 genotipos colectados en 38 áreas de muestreo de 24 países. Se midieron las pérdidas de grano de maíz (PGM), la producción total de polvo (PTP) y el número de insectos adultos (NPA), en bioensayos con GM y de BGG. Los valores de susceptibilidad se asociaron con la referencia geográfica. El intervalo de resistencia al GM fue de $0.6 \%$ a $51 \%$, y al BGG fue de $0.1 \%$ a 66 $\%$. Una fracción de $28 \%$ de los genotipos mostró una alta resistencia a GM, provenientes de los territorios de las Antillas, y de las razas EarCar, Chande, Haitye, Nal-Tel, Tuson, y Canill. La resistencia al BGG fue de $22 \%$ con genotipos asociados a áreas del sureste de México y con las razas Cónico, Nal-Tel, Vandeño, Elotes Occidentales, Cubano, Tuxpeño y Tepecintle. La correlación entre la resistencia de maíz al GM y al BGG fue baja $(\mathrm{r}=0.25 ; \mathrm{P}<0.001)$. Los datos geográficos indicaron una correlación negativa entre la latitud y la longitud con los datos de resistencia al GM $(r=-0.253 ; P<0.001)$. Una tendencia opuesta de correlación, positiva pero no significativa, fue observada para los valores de resistencia al BGG. Estos resultados indican un efecto de la localización geográfica en el desarrollo y la dispersión de las respuestas naturales de resistencia a los insectos. Se identificaron genotipos con una alta resistencia a plagas poscosecha que podrían utilizar los mejoradores de maíz en el desarrollo de cultivares mejorados para AL.

Palabras clave: Zea mays, criollos, gorgojo del maíz, barrenador del grano, resistencia a insectos.

\section{INTRODUCTION}

Maize (Zea mays L.) is a staple crop for food and feed in developing world. Post-harvest losses of maize due to storage insect pests, such as maize weevil (MW) Sitophilus zeamais (Motschulsky, Coleoptera: Curculionidae) and the larger grain borer (LGB) Prostephanus truncatus (Horn, Coleoptera: Bostrichidae), are an increasingly important constraint of food security worldwide (FAO, 2009). Subsistence farmers of developing countries of Latin America (LA) and Africa often experience grain damage exceeding $30 \%$ during on-farm storage due to storage pests (Tigar et al., 1994; Bergvinson and García-Lara, 2004).

The MW is one of the major insect pests of stored maize throughout the world (Pingali and Pandey, 2001). This insect is considered a primary pest, infesting maize both before and after harvest. The MW occurs in over $60 \%$ of 
the field and stored maize in México and LA, causing the most damage in humid areas (Tigar et al., 1994; Bergvinson, 2001). The LGB is a woodborer and an invasive post-harvest insect pest native from Mesoamerica that has acquired the status of serious pest in several of North and LA countries (Markham et al., 1994; Tigar et al., 1994; Kumar, 2002). Studies in LA have shown that subsistence farmers of tropical and subtropical agroecologies experience from 10 to 45 $\%$ maize losses and from 10 to $80 \%$ of damages caused by LGB attack in storage (Tigar et al., 1994; Bergvinson, 2001).

To diminish insect attack, host plant resistance has become an important component of integrative pest management practices (Markham et al., 1994). This strategy has been associated to the discovery, development and use of insect resistant varieties (Dobie, 1977) to reduce post-harvest losses and maintenance of grain quality (García-Lara and Bergvinson, 2007). This effort should be accomplished by the study and access to global genetic resources. Fortunately, maize landraces collected by International Maize and Wheat Improvement Center (CIMMYT) during the past 40 years in collaboration with national and international institutions, represent worldwide diversity of 23409 accessions of maize from México, the Caribbean, Central, and South America (Taba et al., 1998, 1999; Ortiz et al., 2010).

Using this important genetic resource, several maize landraces such as Sinaloa-35 of Chapalote race, México-55 of Palomero-Toluqueño, and Yucatán-7 of race Nal-Tel have been identified and characterized as sources of resistance to MW (Dobie, 1977; Widstrom et al., 1983; Giga and Mazarura, 1991; Arnason et al., 1994) and LGB (Arnason et al., 1997; Kumar, 2002). Maize resistant varieties have been found to suffer only 13 to $50 \%$ as much grain weight loss compared to susceptible counterparts (García-Lara et al., 2007). Mechanisms of resistance include at least two biochemical processes (Arnason et al., 1997): 1) Mechanical fortification or strengthening of the pericarp cell walls that act as physical barrier (Bergvinson and García-Lara, 2004; García-Lara et al., 2004), and 2) Antibiosis, the toxic effects of compounds localized in the aleurone layer (García-Lara et al., 2007; Winkler and García-Lara, 2010).

In the last decade, important efforts have been made to develop resistant maize populations against LGB and MW using Caribbean accessions (Bergvinson, 2001; Kumar, 2002). Unfortunately, few inbred lines derived from these landraces have been incorporated into the breeding programs (Bergvinson and García-Lara, 2003), in part due to lack of interest in postharvest problems and to the fact that the major agronomic priority is still yield, highlighting the necessity to explore more diversity in the germplasmbank for novel sources of insect resistance adapted to Latin American environments. Due to the climatic change, more problems with seed supply for small farmers (Bellon et al., 2011) and postharvest pest are expected, especially in maize varieties available in the market that have never been selected for this trait.

The purpose of the present study was to evaluate the variability of postharvest insect resistance among 1171 native maize races from México (455) and LA (716), within the context of MW and LGB attack. The objectives were: (1) To determine resistance traits for MW and LGB under bioassay in whole grain of 1171 maize genotypes; (2) To identify maize landraces with high resistance to MW and LGB in a germplasm bank collection; and (3) To correlate resistance parameters of both insects with geographical information.

\section{MATERIALS AND METHODS}

\section{Passport data of maize landraces from Latin America}

One thousand one hundred seventy one (1171) maize landraces available at the CIMMYT germplasm bank were used in the current study (Table 1). Criteria of selection were based on previous studies where landraces were detected as sources of insect resistance. Selected landraces originated from 38 sampling locations in 24 Latin America countries were related to groups of maizes such as "cónicos" (G1 group), "tropicales precoces" (G5 group), "dentados tropicales" (G6 group), and "maduracion tardía" (G7 group). Each accession was scored for country, state, geographic coordinates (latitude and longitude), altitude and collection origin, based on germplasm bank of CIMMYT (Figure 1).

Geographic area of this study was selected between $1.2^{\circ}$ to $27.2^{\circ} \mathrm{N}$ and 51.6 to $111.0^{\circ} \mathrm{E}$, and was mainly constituted by territories of México, Caribbean and Antilleans Islands under 220 meters above sea level, masl (Figure 1). Landraces were selected based on passport data related to their agronomic performance and use by the local farmers. Selected landraces were fixed at 1171 genotypes for this specific study, representing $5 \%$ of CIMMYT total accessions.

\section{Seed increase of maize landraces}

Seed was increased during 2004 at the experimental station of CIMMYT at Tlaltizapán, Morelos, México (18 $41^{\circ}$ $\mathrm{N}, 940$ masl). Plots were managed following the standard agronomic recommendations for that region. Self-pollinated ears were handled separately for their use within insect bioassays. Ears were sun dried for $2 \mathrm{~d}$ in an insecticide-free environment, air dried at $35^{\circ} \mathrm{C}$ using a forced air dryer for $3 \mathrm{~d}$, shelled and stored at $13 \%$ grain moisture and $4{ }^{\circ} \mathrm{C}$ until used. 
Table 1. Passport data and number of maize accessions of tropical maize landraces collected by CIMMYT germplasm bank from Latin America.

\begin{tabular}{|c|c|c|c|c|c|c|}
\hline \multicolumn{3}{|c|}{ Sampling area } & \multicolumn{3}{|c|}{ Average } & \multirow{3}{*}{$\begin{array}{l}\text { Accession } \\
\text { s/location }\end{array}$} \\
\hline \multirow{2}{*}{ ID } & \multirow{2}{*}{ Location } & \multirow{2}{*}{ Country } & Lat $(\mathrm{N})$ & Long (W) & \multirow{2}{*}{ Altitude (m) } & \\
\hline & & & \multicolumn{2}{|c|}{$\circ$} & & \\
\hline 1 & Sonora & México & 27.2 & 111.0 & 14 & 2 \\
\hline 2 & Sinaloa & México & 24.5 & 107.2 & 85 & 5 \\
\hline 3 & Nayarit & México & 21.6 & 105.2 & 6 & 44 \\
\hline 4 & Colima & México & 18.5 & 103.5 & 45 & 7 \\
\hline 5 & Guerrero & México & 17.4 & 101.3 & 75 & 46 \\
\hline 7 & Veracruz & México & 20.6 & 97.2 & 15 & 153 \\
\hline 8 & Oaxaca & México & 16.2 & 95.1 & 44 & 28 \\
\hline 9 & Tabasco & México & 17.6 & 93.2 & 23 & 4 \\
\hline 10 & Chiapas & México & 15.3 & 92.5 & 79 & 27 \\
\hline 11 & Campeche & México & 19.1 & 90.2 & 28 & 33 \\
\hline 12 & Yucatán & México & 20.6 & 89.0 & 13 & 104 \\
\hline 13 & Quintana Roo & México & 19.3 & 88.0 & 18 & 2 \\
\hline 14 & Guatemala & Guatemala & 15.4 & 88.3 & 36 & 38 \\
\hline 15 & Salvador & El Salvador & 13.3 & 88.1 & 162 & 30 \\
\hline 16 & Honduras & Honduras & 15.5 & 87.5 & 29 & 42 \\
\hline 17 & Nicaragua & Nicaragua & 12.1 & 85.2 & 98 & 12 \\
\hline 18 & Costa Rica & Costa Rica & 10.1 & 83.3 & 218 & 211 \\
\hline 19 & Panamá & Panamá & 9.2 & 79.5 & 9 & 58 \\
\hline 20 & Cuba & Cuba & 21.3 & 78.1 & 60 & 39 \\
\hline 21 & Jamaica & Jamaica & 18.3 & 77.5 & 46 & 5 \\
\hline 22 & Magdalena & Colombia & 10.3 & 75.3 & 50 & 2 \\
\hline 23 & Atlántico & Colombia & 10.5 & 75.1 & 52 & 6 \\
\hline 24 & Córdova & Colombia & 8.4 & 75.5 & 27 & 2 \\
\hline 25 & Haití & Haití & 19.3 & 72.4 & 146 & 22 \\
\hline 26 & Rep. Dominicana & Rep. Dominicana & 19.5 & 70.4 & 78 & 52 \\
\hline 27 & Puerto Rico & Puerto Rico & 18.1 & 67.1 & 30 & 27 \\
\hline 28 & San Cristóbal & San Cristóbal & 17.2 & 62.5 & 0 & 11 \\
\hline 29 & San Vicente & San Vicente & 13.1 & 61.1 & 19 & 23 \\
\hline 30 & Santa Lucía & Santa Lucía & 13.5 & 60.6 & 78 & 2 \\
\hline 31 & Antigua & Antigua & 17.0 & 61.5 & 49 & 8 \\
\hline 32 & Grenada & Granada & 12.0 & 61.4 & 160 & 26 \\
\hline 33 & Guadalupe & Guadalupe & 15.6 & 61.4 & 31 & 31 \\
\hline 34 & Trinidad y Tobago & Trinidad y Tobago & 10.4 & 61.3 & 65 & 37 \\
\hline 35 & Barbados & Barbados & 13.1 & 59.4 & 70 & 15 \\
\hline 36 & Guyana & Guyana & 6.5 & 58.1 & 3 & 2 \\
\hline 37 & Guyana & Guyana Francesa & 5.5 & 55.1 & 5 & 4 \\
\hline \multirow[t]{3}{*}{38} & Amapa & Brazil & 1.2 & 51.6 & 135 & 11 \\
\hline & & Mín & 1.2 & 51.6 & 0 & 2.0 \\
\hline & & Máx & 27.2 & 111.0 & 218 & 211.0 \\
\hline
\end{tabular}




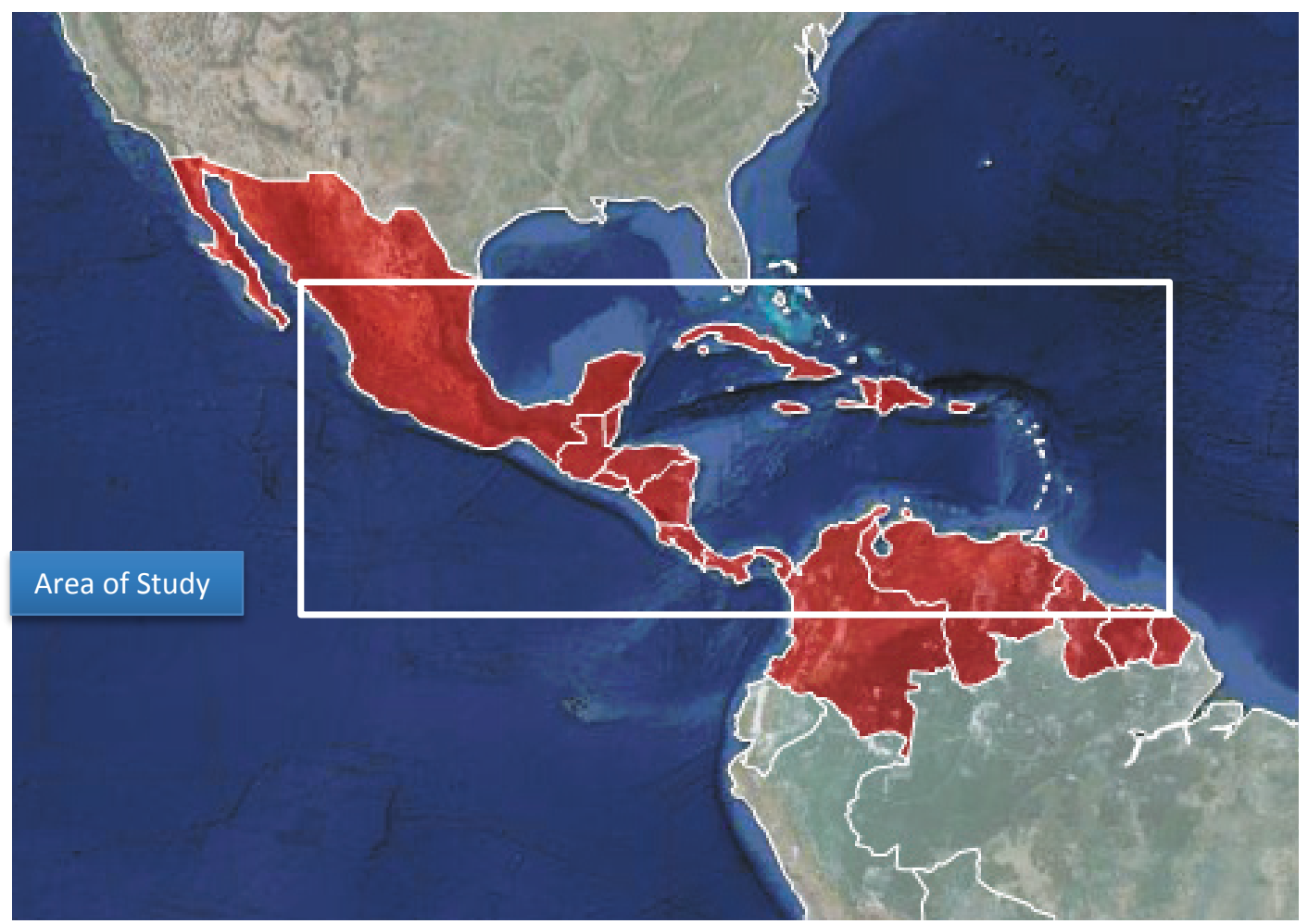

Figure 1. Selected area of study for discovery of new sources of maize landraces resistant to storage pest.

\section{Maize weevil resistance bioassay}

Cultures were developed and maintained using the methods described by García-Lara et al. (2009). Briefly, a MW colony was collected from Poza Rica, Veracruz and cultured on the hybrid CML244 x CML349 for four cycles at $27 \pm 1{ }^{\circ} \mathrm{C}$ and $70 \pm 5 \% \mathrm{RH}$. Grain was equilibrated for 30 d at $27 \pm 1{ }^{\circ} \mathrm{C}$ and $70 \pm 5 \%$ of relative humidity prior to infestation. For insect bioassays, three separated replicates were used in the evaluation. Each replicate contained $30 \mathrm{~g}$ of maize grain and was infested with 25 adult weevils 0 to 7 days-old. The adults were removed after 1 week. After 12 weeks, mesh sieves (\#10 and \#16) were used to separate grain, adult weevils and dust. Grain weight loss, adult progeny, and total dust production were recorded. Resistant (Pop. 84) and susceptible (CML244X256) checks were included for comparison.

\section{Large grain borer resistance bioassay}

The LGB colony was collected in Oaxaca, México, and renewed every 8 months. Insects were cultured on maize hybrid CML460 x CML461, a single- cross dent highland hybrid, for four cycles at $27 \pm 1{ }^{\circ} \mathrm{C}, 70 \pm 5 \%$ relative humidity $(\mathrm{RH})$ and 12:12 h light and dark (L:D). Cultures were maintained and renewed using the methods described by Bergvinson et al. (2001). Briefly, P. truncatus was reared in
$0.5 \mathrm{~L}$ glass jars with vented lids that were filled with $400 \mathrm{~g}$ of equilibrated maize $\left(30 \mathrm{~d}\right.$ at $27 \pm 1{ }^{\circ} \mathrm{C}, 70 \pm 5 \%$ of $\left.\mathrm{RH}\right)$ covered with $10 \mathrm{~g}$ of maize flour and infested with 250 unsexed adults. Adults progenies were collected after 6 to 8 weeks.

P. truncatus adults were obtained by sieving (\#10 and \#16; USA Standard Testing Sieve E-11 ${ }^{\mathrm{Tm}}$, (Seedburo Equipment Company, Chicago IL, USA) maize containing grain damage greater than $50 \%$. For bioassay, three replicates were conducted on a jar with $30 \mathrm{~g}$ samples of maize, which were allowed to equilibrate at $13 \%$ of grain humidity for 3 weeks prior to infestation with LGB. Each jar was infested with 25 unsexed adults of LGB ( 0 to $7 \mathrm{~d}$ old). After 8 weeks the grain was sieved using mesh sieves (\#10 and \#16) to separate grain, dust, and adult insects. Grain weight loss, dust production, adult emergence were recorded.

\section{Statistical analysis}

Resistance data were subjected to analysis of variance using the statistical software Statistix v.7 (Analytical Software, Tallahassee, FL) and differences among means were compared by LSD test at $\mathrm{P}<0.05$. To summarize the data, means were calculated per region or country. Best accessions were elected using a simple sort analysis based on an index (all traits were converted to maximum of 1 and then the total average was calculated) which included all resistance traits 
for each pest. Statistix also calculated Pearson correlations among resistance traits and geographic data.

\section{RESULTS AND DISSCUSION}

\section{Resistance of maize landraces to maize weevil}

Geographic area of this study (Figure 1) has been used before to find and study sources of maize postharvest insect resistance with high success (Arnason et al., 1994; Kumar, 2002). Selected landraces represented $5 \%$ of CIMMYT total accessions (Table 1). Considerable variation in MW resistance traits was observed among 1171 maize landraces accessions (Figure 2). Significant differences between genotypes were observed for grain weight losses (GWL), total dust production (TDP) and number of adult progeny (NAP). Range of response to GWL, TDP and NAP were observed from 0.6 to $51 \%, 0.3$ to $4.9 \mathrm{~g}$, and 6 to 197 adults, respectively. A fraction of $28 \%$ of the 1175 genotypes analyzed showed a high level of resistance to MW. Compared with previous studies (Serratos et al., 1987; Giga and Mazarura, 1991; García-Lara et al., 2003; Abebe et al., 2009), high incidence of resistance response was observed in the germplasm fraction used in this study.

\section{Resistance of maize landraces to large grain borer}

Comparative results based on MW were observed in LGB resistance traits among 1171 maize landraces accessions (Figure 3). Significant differences between genotypes were also observed for GWL, TDP and NAP after 8 weeks of infestation. Compared to MW, LGB required less time in bioassay because of its voracity (Nansen and Meikle, 2002). Range of response to GWL, TDP and NAP were observed from 0.1 to $66 \%, 0.1$ to $13 \mathrm{~g}$, and 20 to 231 adults, respectively. In general, more GWL (22 \%), TDP (65\%) and NAP (14\%) were found for LGB compared with MW. This damage is related to LGB biology, which is characterized by 35 weeks longevity, high flight activity, and reproduction under wide spectrum of conditions (Farrell, 2000; Golob, 2002; Nansen and Meikle, 2002). Present results confirm the fact that LGB causes major losses compared to MW, as formerly proposed by Meikle et al. (1998). Levels of resistance were higher compared with previous studies (Bergvinson, 2001; Kumar, 2002; Mwololo et al., 2012).

\section{Highly resistance maize landraces}

The discovery and identification of new sources with higher resistance to MW and LGB in maize germplasm of LA was achieved in this study (Table 2). Arnason et al. (1994) reported important levels of MW resistance in native maize races collected in Belize area. In this study the novel germplasm fraction of MW resistance was associated to wet lowland areas of Antilles islands with maize landraces collected from Guadalupe, Rep. Dominicana, Haiti, Puerto Rico and Yucatán, México. Novel high resistant landraces include EarCar, Chande, Haitye, Nal-Tel, Tuson, and Canill (Table 2). Maize varieties resistant to LGB have been recognized from African and Caribbean accessions (Arnason et al., 1994; Kumar, 2002). However, this study showed novel sources of resistance for LGB identified from Southern México, including states such as Nayarit, Guerrero, Oaxaca, Campeche, Veracruz, and Yucatán. Novel higher resistant landraces included Cónico, Nal-Tel, Vandeño, Elotes Occidentales, Cubano, Tuxpeño, and Tepecintle (Table 2).

\section{Relationship between MW resistance, LGB resistance, and geographic data}

Maize weevil GWL, TDP and NAP were correlated to each other $(r>0.89 ; \mathrm{P}<0.001)$. Similar statistical responses were observed for LGB resistance traits. Although MW and LGB have different biology, evolutionary history, agro-ecologies, and habitats (Dobie, 1977; Longstaff, 1981; Nansen and Meikle, 2002), resistance traits were compared between response of maize against MW and LGB attack (Table 3). As expected, the relationship between MW and LGB traits was low indicating a divergent adaptive response of maize grain to insects. This result highlights the importance of performing divergent selection of postharvest insect resistance germplasm in the breeding programs.

Geographic data were also correlated with MW and LGB traits (Table 3). Geographic coordinates showed a negative correlation between latitude and longitude with GWL, TDP and NAP for the maize weevil $(\mathrm{r}=-0.177, \mathrm{r}=-0.253, \mathrm{r}=$ -0.251 , at $\mathrm{P}<0.05$, respectively). Opposite trend of correlations, positive but not significant, was observed for LGB resistant traits LGB. Latitudinal trend (low north latitude) is related to high humidity, temperature and insect diversity (Zhang et al., 2011), conditions which allow better conditions for insect development and more insect-plant interactions for natural development of resistance.

But in contrast, longitude has no established biological interpretation. Because in this study locations were located in tropical environments, starting in longitude of $51.6^{\circ} \mathrm{S}$ (Amapa, Brazil) and finishing at $111^{\circ} \mathrm{N}$ (Sonora, México), it is possible that this correlation is due to temperature range. This is also supported by the fact that latitude was significantly correlated with longitude for this area $(r=$ $0.356, \mathrm{P}<0.001)$. In fact, this indicates the important influence of geographic location for developing maize resistance to postharvest pests.

This can be related to human practices in agriculture, where through years of human selection, properties of storage have 


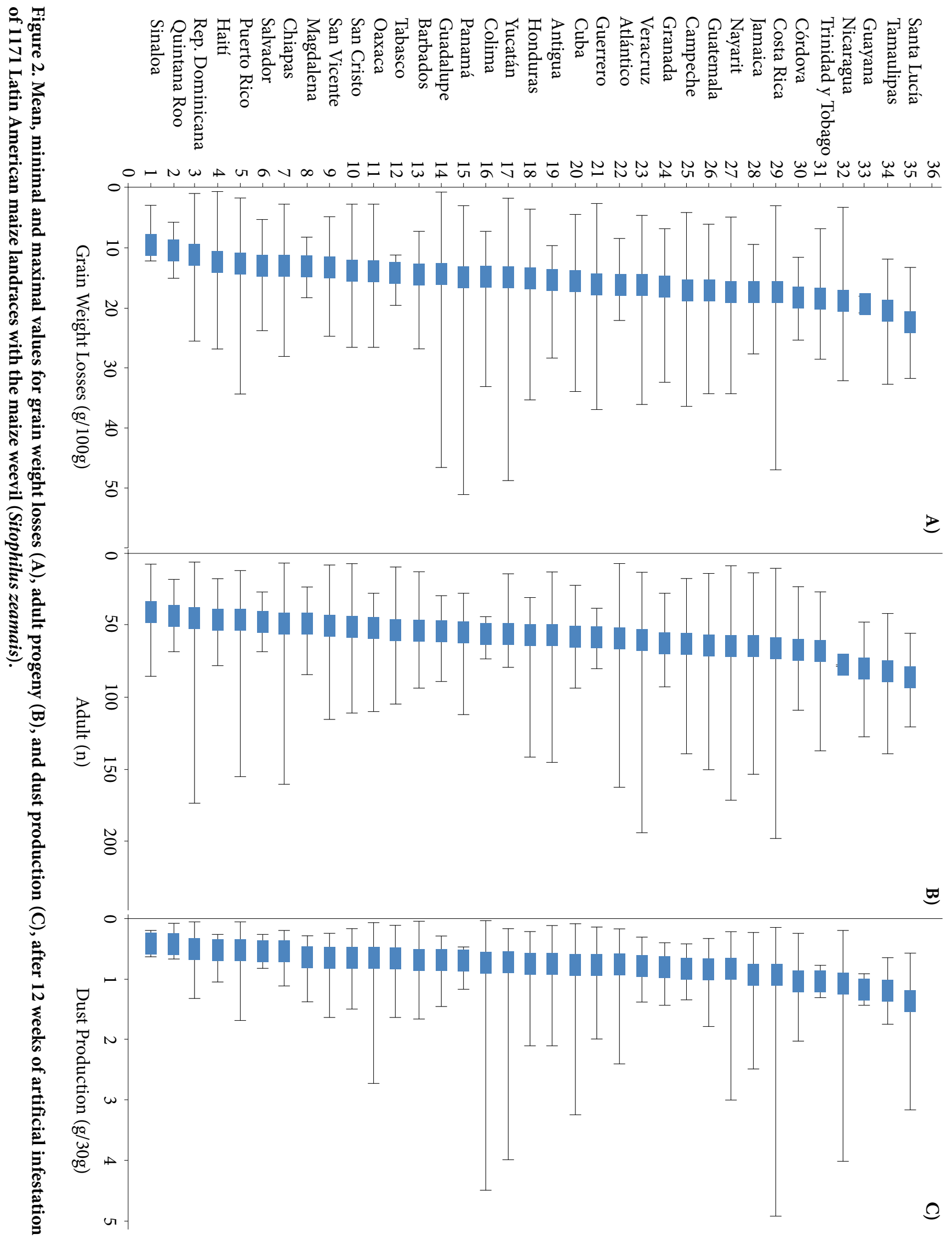




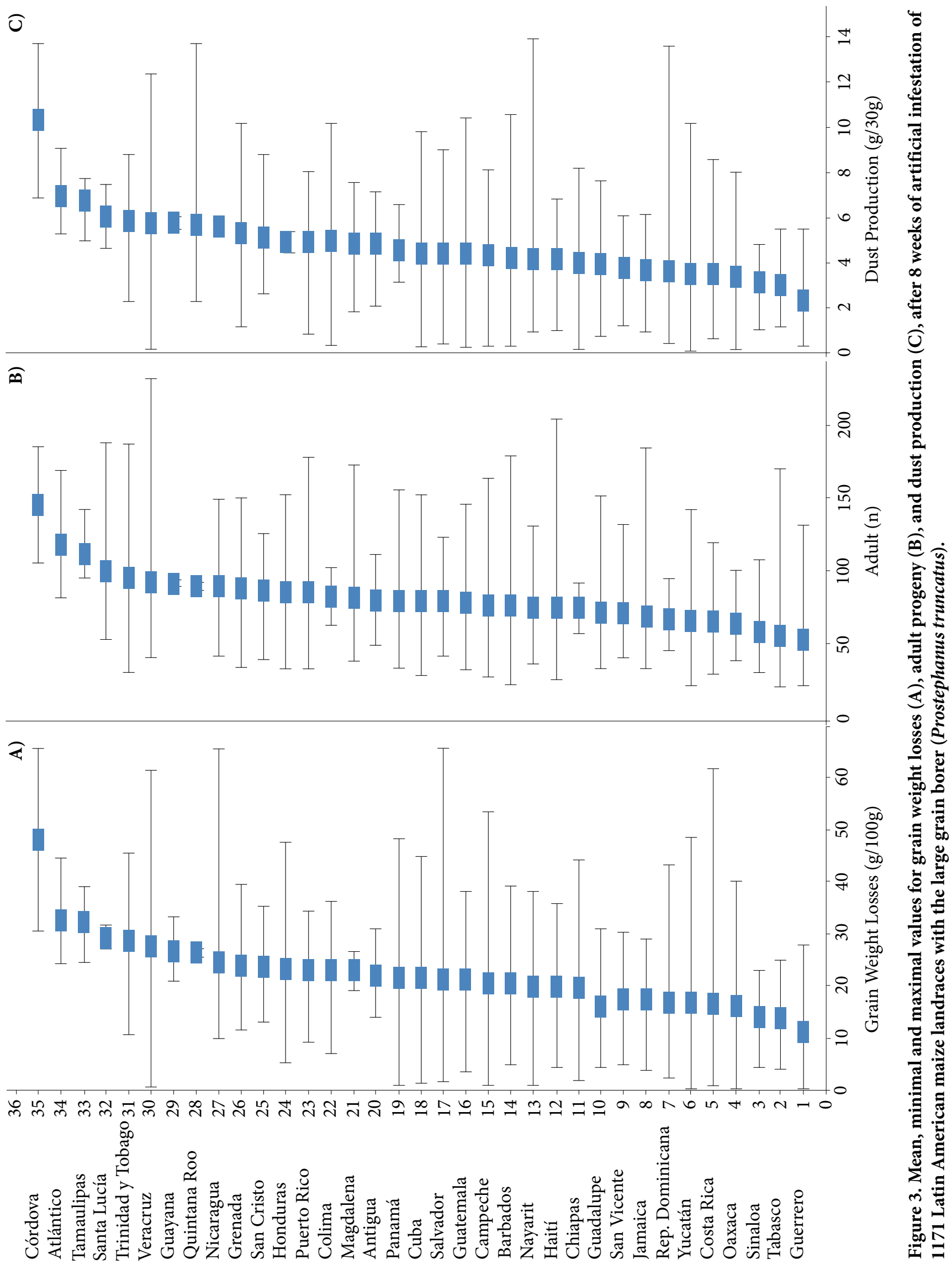


Table 2. Maize genotypes identified with best postharvest insect resistance from 1171 Latin American maize landraces accession at CIMMYT germplasm bank.

\begin{tabular}{|c|c|c|c|c|c|}
\hline No. & CIMMYT bank accession $^{\dagger}$ & Pedigree & Race & Group $^{\dagger \dagger}$ & Index \\
\hline & & & & & Maize weevil \\
\hline 1 & СIMМYТМА-003891 & Guadalupe 16 & EarCar & G6 & 0.08 \\
\hline 2 & CIMMYTMA-001322 & Rep. Dominicana 259 & Chande & nd & 0.09 \\
\hline 3 & CIMMYTMA-001307 & Haití 20 & Haitye & nd & 0.1 \\
\hline 4 & CIMMYTMA-002358 & Yucatán 151 & Nal-Tel & G6 & 0.11 \\
\hline 5 & CIMMYTMA-001333 & Puerto Rico 16 & Tuson & G6 & 0.12 \\
\hline 6 & CIMMYTMA-003931 & Rep. Dominicana 246 & Canill & G6 & 0.13 \\
\hline 7 & CIMMYTMA-001261 & Rep. Dominicana 287 & Chande & G6 & 0.16 \\
\hline 8 & CIMMYTMA-001056 & Guadalupe 11 & EarCar & G6 & 0.17 \\
\hline 9 & CIMMYTMA-003948 & Rep. Dominicana 267 & Chande & nd & 0.18 \\
\hline \multirow[t]{2}{*}{10} & СIMMYTMA-003947 & Rep. Dominicana 266 & Chande & nd & 0.19 \\
\hline & & & & & Large grain borer \\
\hline 11 & CIMMYTMA-000103 & Oaxaca 19 & Cónico & G1 & 0.15 \\
\hline 12 & CIMMYTMA-000725 & Campeche 4 & Nal-Tel & G6 & 0.18 \\
\hline 13 & СIMMYTMA-000188 & Guerrero 210 & Vandeño & G6 & 0.18 \\
\hline 14 & СIMMYTMA-000195 & Guerrero 153 & Vandeño & G6 & 0.2 \\
\hline 15 & CIMMYTMA-002557 & Yucatán 15 & Nal-Tel & G6 & 0.23 \\
\hline 16 & CIMMYTMA-000362 & Nayarit 29 & Elotes Occid. & G3 & 0.23 \\
\hline 17 & CIMMYTMA-000984 & Panamá 65 & Cubano & G6 & 0.24 \\
\hline 18 & СIMMYTMA-000473 & Veracruz 187 & Tuxpeño & G6 & 0.27 \\
\hline 19 & СIMMYTMA-003414 & Costa Rica 206 & Tepecintle & G6 & 0.27 \\
\hline 20 & СIMMYTMA-001791 & Yucatán 30 & Nal-Tel & G6 & 0.36 \\
\hline
\end{tabular}

Table 3. Pearson correlations between susceptibility traits to maize weevil MW (Sitophilus zeamais) and to large grain borer LGB (Prostephanus truncates) with geographic data from 1171 Latin American maize landraces.

\begin{tabular}{|c|c|c|c|c|c|c|}
\hline \multirow[b]{2}{*}{ Trait $^{\dagger}$} & \multicolumn{3}{|c|}{ Maize weevil (MW) } & \multicolumn{3}{|c|}{ Larger grain borer (LGB) } \\
\hline & GWL & TDP & NAP & GWL & TDP & NAP \\
\hline MW-TDP & $0.893^{* * *}$ & & & & & \\
\hline MW-NAP & $0.849^{* \star *}$ & $0.827^{\star * *}$ & & & & \\
\hline LGB-GWL & $0.289^{*}$ & $0.271^{\star}$ & $0.179^{*}$ & & & \\
\hline LGB TDP & $0.285^{\star}$ & $0.288^{*}$ & $0.199^{*}$ & $0.957^{\star * *}$ & & \\
\hline LGB-NAP & 0.136 & 0.142 & 0.044 & $0.876^{* \star *}$ & $0.864^{* * *}$ & \\
\hline Latitude & -0.102 & -0.106 & -0.036 & 0.152 & 0.131 & 0.147 \\
\hline Longitude & $-0.177^{\star}$ & $-0.253^{\star}$ & $-0.251^{\star}$ & 0.017 & 0.014 & 0.079 \\
\hline Altitude & 0.069 & 0.057 & 0.076 & 0.056 & 0.050 & 0.024 \\
\hline
\end{tabular}


been selected to ensure food security. Examples of this selection has been reported by Taba et al. (2006) for the Zapalote Chico maize race, where the conservation of this traditional landraces grown by farmers in Latin America has contributed to food security by dispersion and adoption of the new generation of local "criollos". Selection for storage resistance is mainly the role of women (Parvathi et al., 2000), whose decision of maize storage properties include easy shelling and grain quality for tortillas (Keleman and Hellin, 2009).

Tropical areas are the most severely impacted by MW and LGB damage (Bellon et al., 2005); however, the use and adoption of identified landraces or improved varieties (generated with novel sources of landraces resistance) could help reduce losses and maintain maize diversity in LA. Finally, the application of this study could lead to new insights into the patterns of landraces genetic diversity within LA maize accessions (Prasanna, 2012), helping to track migration routes of maize from the centers of origin, and understanding the genetic diversity during maize domestication.

\section{CONCLUSIONS}

This study identified novel maize landraces with high levels of resistance to MW and LGB from Latin American accessions from 24 countries. The best sources for MW resistance were associated to areas of Antilles, while for LGB the best sources were collected from Southern México. Genotypes with high postharvest insect resistance have now been identified for maize breeders to use in developing improved cultivars in Latin American, for reducing postharvest losses and increase food security.

\section{ACKNOWLEDGEMENTS}

We gratefully acknowledge the financial support of MASAGRO for the project "Calidad en Maíces Nativos Mexicanos", and to the Canadian International Development Agency (CIDA) for the project "Reducing Postharvest Losses in Maize". Technical reviews of the manuscript by S. Serna, N. Palacios and M. Willcox are gratefully acknowledged.

\section{BIBLIOGRAPHY}

Abebe F, T Tefera, S Mugo, Y Beyene, S Vidal (2009) Resistance of maize varieties to the maize weevil Sitophilus zeamais (Motsch.) (Coleoptera: Curculionidae). African J. Biotechnol. 8:5937-5943.

Arnason J T, B Baum, J Gale, J D H Lambert, D Bergvinson, B J R Philogène, J A Serratos, J Mihm, D C Jewell (1994) Variation in resistance of Mexican landraces of maize to maize weevil Sitophilus zeamais, in relation to taxonomic and biochemical parameters. Euphytica 74:227-236.

Arnason J T, B Conilh de Beyssac, B J R Philogéne, D Bergvinson, J A Serratos, J A Mihm (1997) Mechanism of resistance in maize grain to the maize weevil and the larger grain borer: In: Insect
Resistance Maize: Recent Advances and Utilization. Proc. Int. Symp. held at CIMMYT. J A Mihm (ed). CIMMYT. Mexico D.F. pp:91-95.

Bellon M R, D Hodson, D Bergvinson, D Beck, E Martinez-Romero, Y Montoya (2005) Targeting agricultural research to benefit poor farmers: relating poverty mapping to maize enviroments in Mexico. Food Policy 30:476-492.

Bellon M R, D Hodson, J Hellin (2011) Assessing the vulnerability of traditional maize seed systems in Mexico to climate change. Proc. Natl. Acad. Sci. USA 108:13432-13437.

Bergvinson D J (2001) Storage pest resistance in maize. In: Maize Research Highlights 1999-2000. Maize Program (ed). CIMMYT. Mexico D.F. pp:32-39.

Bergvinson D J, S Garcia-Lara (2003) Advances in tropical maize resistance to storage pests. In: Arnel R. Hallauer Intl. Symp. on Plant Breeding. CIMMYT (ed). Mexico, D.F. pp:12-16.

Bergvinson D J, S García-Lara (2004) Genetic approaches to reducing losses of stored grain to insects and diseases. Curr. Opin. Plant Biol. 7:480-485.

Dobie P (1977) The contribution of the Tropical Stored Products Centre to the study of insect resistance in stored maize. Trop. Stored Prod. Inf. 34:7-22.

FAO, Food and Agricultural Organization (2009) Post-harvest Losses: Aggravate Hunger. Media Center-FAO, Rome, Italy. Available at: http://www.fao.org/news/story/jp/item/36844/icode/ (September 2013).

Farrell G (2000) Dispersal, phenology and predicted abundance of the larger grain borer in different environments. African Crop Sci. J. 8:337-343.

García-Lara S, M M Khairallah, M Vargas, D J Bergvinson (2009) Mapping of QTL associated with maize weevil resistance in tropical maize. Crop Sci. 49:139-149.

García-Lara S, D J Bergvinson (2007) Integral program to reduce postharvest losses in maize. Agric. Téc. Méx. 33:181-189.

García-Lara S, A J Burt, J A Serratos, D M Díaz-Pontones, J T Arnason, D J Bergvinson (2003) Defensas naturales en el grano de maíz al ataque de Sitophilus zeamais (Motsch Coleoptera: Curculionidae): mecanismos y bases de la resistencia. Rev. Educ. Bioquím. 22:138-145.

García-Lara S, D J Bergvinson, A J Burt, A I Ramputh, D M Díaz-Pontones, J T Arnason (2004) The role of pericarp cell wall components in maize weevil resistance. Crop Sci. 44:1546-1552.

García-Lara S, J T Arnason, D Díaz-Pontones, E Gonzalez, D J Bergvinson (2007) Soluble peroxidase activity in maize endosperm associated with maize weevil resistance. Crop Sci. 47:1125-1130.

Giga D P, U W Mazarura (1991) Levels of resistance to the maize weevil Sitophilus zeamais (Motsch.) in exotic, local open-pollinated and hybrid maize germplasm. Int. J. Trop. Insect Sci. 12:159169.

Golob P (2002) Chemical, physical and cultural control of Prostephanus truncatus. Integr. Pest Manage. Rev. 7:245-277.

Keleman A, J Hellin (2009) Specialty maize varieties in Mexico: a case study in market-driven agro-biodiversity conservation. J. Latin Am. Geogr. 8:147-174.

Kumar H (2002) Resistance in maize to the larger grain borer, Prostephanus truncatus (Horn) (Coleoptera: Bostrichidae). J. Stored Prod. Res. 38:267-280.

Longstaff B C (1981) Biology of the grain pest species of the genus Sitophilus (Coleoptera: Curculionidae): a critical review. J. Protect. Ecol. 3:83-130.

Markham R H, C Borgemeister, W G Meikle (1994) Can biological control resolve the larger grain borer crisis? In: Proc. 6th Int. Working Conf. on Stored-Product Protection. Vol. 2. E Highley, E J Wright, H J Banks, B R Champ (eds). CAB International, Wallingford Canberra, Australia. pp:1087-1097.

Meikle W G, C Adda, K Azoma, C Borgemeister, P Degbey, B Djomamou, R H Markham (1998) The effects of maize variety on the density of Prostephanus truncatus (Coleoptera: Bostrichidae) and Sitophilus zeamais (Coleoptera: Curculionidae) in postharvest stores in Benin Republic. J. Stored Prod. Res. 34:45-58.

Mwololo K J, S N Mugo, T Tefera, P Okori, S W Munyiri, K Semagn, M Otim, Y Beyene (2012) Resistance of tropical maize genotypes to the larger grain borer. J. Pest Sci. 85:267-275.

Nansen C, W G Meikle (2002) The biology of larger grain borer, Prostephanus 
truncatus (Horn) (Coleoptera: Bostrichidae). Integr. Pest Manage. Rev. 7:91-104.

Ortiz R, S Taba, V H Chávez T, M Mezzalama, Y Xu, J Yan, J H Crouch (2010) Conserving and enhancing maize genetic resources as global public goods-a perspective from CIMMYT. Crop Sci. 50:13-28.

Parvathi S, K Chandrakandan, C Karthikeyan (2000) Women and dryland post-harvesting practices in Tamil Nadu, India. Indigen. Knowl. Develop. Monitor 8:13-16.
Pingali P L, S Pandey (2001) Meeting world maize needs: technological opportunities and priorities for the public sector. In: CIMMYT 1999-2000: World Maize Facts and Trends. Meeting World Maize Needs: Technological Opportunities and Priorities for the Public Sector. P L Pingali (ed). CIMMYT, Mexico City. pp:1-20.

Prasanna B M (2012) Diversity in global maize germplasm: characterization and utilization. J. Bioscience 37:843-855 